\title{
Effect of fly ash on the bearing capacity of stabilised fine sand
}

1 Siavash Mahvash BSC

PhD candidate, School of Computing and Technology, University of West London, London, UK

2 Susana López-Querol PhD, MEng, CEng, MICE, FHEA Senior Lecturer, Department of Civil, Environmental and Geomatic Engineering, University College London, London, UK

(corresponding author: s.lopez-querol@ucl.ac.uk)

(Orcid:0000-0002-2677-3007)
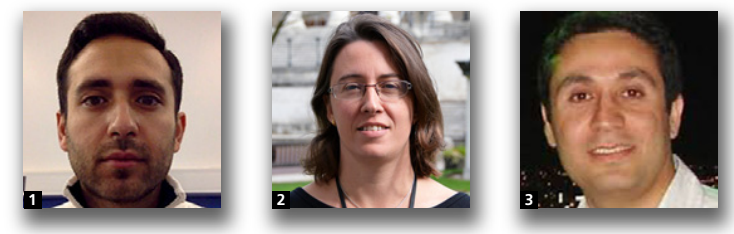

3 Ali Bahadori-Jahromi PhD, MSC, BEng, FICE, CEng Associate Professor, School of Computing and Technology, University of West London, London, UK

This paper is concerned with the role of fly ash (FA) content in the California bearing ratio (CBR) values of stabilised sandy soil for geotechnical and geoenvironmental infrastructure. A series of laboratory tests - particle size distribution and CBR tests, were performed. The literature review demonstrates the shortage of research on the stabilisation of sandy material with FA. The main focus of this paper is to establish the optimal quantity of FA content for the stabilisation of this type of soil. A total of 14 distinctive variations of stabilised sand is presented, with three different FA content percentages (5, 10 and 15\%), three main curing periods, with durations of 1, 2 and 4 weeks, and a constant cement content of $3 \%$. Some samples were treated with only 3 and $5 \%$ cement, with no addition of FA, so that the effect of cement on this particular sand could be observed, and the contribution of the FA alone could be understood. The results obtained are in line with the literature for other types of soil.

\section{Introduction}

Coal-fired power plants around the world produce nearly $25 \%$ of the world's primary energy needs, or in other words, $38 \%$ of the worldwide electricity is generated from these coal-fired power plants (Barnes and Sear, 2006). Coal combustion products (CCPs) are the residues generated in coal-fired power stations by burning coal as fuel. Fly ash (FA) constitutes about $80 \%$ of the total coal ash produced worldwide (Abmaruzzaman, 2010). In general, most of the FA produced is disposed of in landfill, causing concerns for environmental agencies. An increase in the utilisation of FA would lead to lower disposal rates, less land being used for landfills and replacement of traditional base materials so that carbon dioxide emissions can be lowered. This paper is focused on the utilisation of FA only, as it has proved to be a more viable soil stabiliser in comparison to bottom ash, due to its finer particle size.

This study is concerned with the influence of FA on stabilised sandy soil. Its effect is investigated and analysed through some laboratory tests, such as the particle size distribution (PSD) and California bearing ratio (CBR) tests. The chief aim of the study presented in this paper is to examine the suitability of Class F FA as a suitable material for the construction of embankments in geotechnical engineering projects. In the following section of this paper, the background, consisting of a revision of previous relevant research, is outlined. After that, the methodology followed to carry out this work is explained in detail, followed by the discussion of results and main derived conclusions.

\section{Background}

Throughout the past decades, FA has been considered a problematic solid waste due to the conventional disposal methods of thermal power plants and factories, as arable lands all around the world have been contaminated and degraded. As the planet's fifth-largest raw material resource (Abmaruzzaman, 2010), FA can be used as an alternative to conventional materials in the construction of geotechnical and geoenvironmental infrastructure. Diminishing and/or minimising mining and quarrying for naturally occurring resources, and instead using CCPs as a replacement, can lead to sustainable and environmental gains. Energy demand and emissions into the atmosphere can also be reduced by utilising CCPs (Barnes and Sear, 2006).

FA production, utilisation and disposal rates in the UK from 1999 to 2013 are illustrated in Figure 1. It can be seen that, from 1999 to 2003, landfill use rates were higher than the FA utilisation rate; however, from 2003 onwards they have been lower than the FA utilisation rate. Although in $2010,36 \%$ of the 


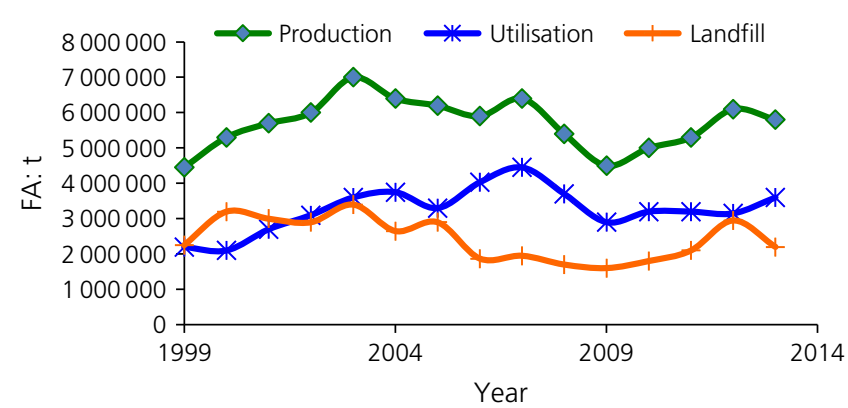

Figure 1. UK FA production, utilisation and landfill values (after Carroll, 2015; UKQAA, 2016)

total FA produced was sent to landfills, this increased to $48 \%$ in 2012, whereas the utilisation amount remained at around $32 \mathrm{Mt}$, and then in 2013, the rate of landfill use dropped to $38 \%$. The relative utilisation and production of FAs differ noticeably from one country to another (Figure 2). It is believed that in the near future, the disposal of FA will become too costly, if not banned altogether (Abmaruzzaman, 2010). This can be seen in the Netherlands, where all FA must be utilised or exported because landfill is prohibited (Eijk et al., 2011).

FA can be utilised for a variety of applications within the construction industry (Figure 3). It can be seen that about $60 \%$ of the total FA produced in the USA is not utilised, making it one of the highest rates of non-utilisation worldwide. In addition, Figure 3 illustrates that nearly $30 \%$ of the FA utilisation in the USA is for the production of cement and concrete products, while utilisation for soil stabilisation, which forms

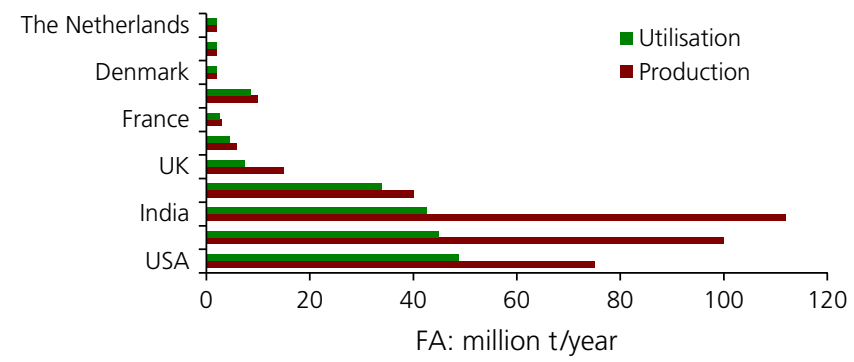

Figure 2. Worldwide FA production and utilisation in various countries (after Pandey and Singh, 2010)

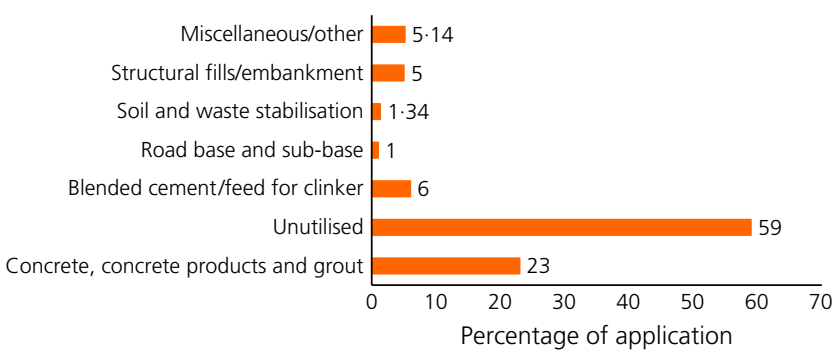

Figure 3. Various FA applications within the USA in 2014 (after ACAA, 2014) the focus of the present study, accounts for $<0 \cdot 5 \%$ of the total production and about $1 \%$ is for waste stabilisation.

The reutilisation of waste materials, such as FA, within the construction industry, and particularly in geotechnical engineering, has a significant potential to minimise the amount of disposed waste materials (Baykal et al., 2004; Cetin and Aydilek, 2013). Celauro et al. (2012) stated that utilisation of FA in the construction of road, railways and airports, due to the volumes of materials used, would have a profound impact, from the environmental point of view, on the surroundings. Cetin and Aydilek (2013) believe that the reutilisation of the FA in embankment construction can lead to several benefits

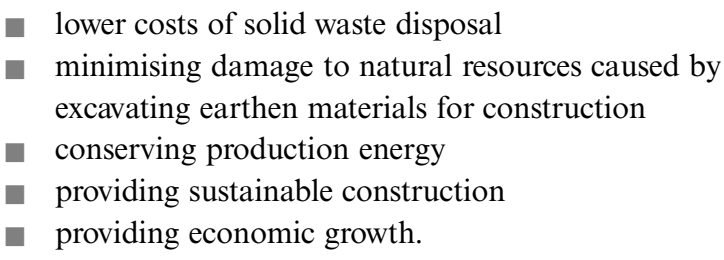

\subsection{Ground improvement and stabilisation using FA} Ground improvement can be defined 'as the introduction of materials or energy to soils to effect a change in performance of the ground such that it performs more reliably and can be incorporated into the design process' (Essler, 2012: p. 911). All around the world, the construction of projects with very long design lives, such as embankments, retaining walls and bridges, is made possible by improving the load-bearing capacity and stability of soils through ground-improvement techniques (Cofra, 2005). This generally involves the enhancement of ground properties, principally by strengthening or stiffening processes and compaction or densification mechanisms, to achieve a specific geotechnical performance (Serridge and Slocombe, 2012). In the recent past, the use of ground improvement has increased significantly, as a result of more construction sites being located in areas of poor-quality ground, redevelopment of existing sites and remediation of contaminated sites.

O'Flaherty and Hughes (2016) explain that modification of a soil is used to improve its properties without causing much increase in its elastic modulus or tensile strength, while stabilisation is employed for achieving significant improvements in strength and stiffness. Ground improvement through stabilisation is seen as an economical way of construction by diminishing the number of soil exchanges (Hossain, 2010).

One of the major methods used to solve the problems caused by weak soils is soil stabilisation by mixing with a cementitious binder. The two most common binders are lime and cement. The stabilisation is achieved by the soil particles being glued more chemically than physically. Moreover, dealing with weak soils is one of the most important challenges in the construction industry (Cristelo et al., 2013; Senol et al., 2006), in particular, in road and highway construction or in geotechnical 
engineering (Fauzi et al., 2010; Senol et al., 2006). Therefore, it is vital to find methods of soil improvement so that the demands can be met. Dockter et al. (1999: p. 2) concluded that coal combustion FA has 'excellent potential for use in rammed earth construction as a low-cost alternative to Portland cement and other stabilizers because of its pozzolanic properties'. Soil stabilisation using FA benefits from the enhancement of the compressive strength (CS) of the soft soil (Bergado et al., 1996; Prabakar et al., 2004). Additional benefits of soil stabilisation may include

- improvement of permeability and soil resistance to the weathering process and traffic usage

(Zaliha et al., 2013)

- improvement of the shear strength, filter and drainage system (Prabakar et al., 2004).

Some of the advantages of ground improvement using wastes are reduction of the high cost of building and maintenance of the waste-disposal facilities while increasing the supply of construction material from the waste (Porbaha and Hanzawa, 2001). In considering the performance of newly built embankments, factors apart from the stability of the embankment slope that should be considered are (Manceau et al., 2012)

\section{- failure of the embankment foundation \\ - settlement of the foundation material \\ - self-settlement of the embankment fill.}

Through chemical techniques, 'stabilization can be done using chemical and emulsions since they work as compaction aids, binders, water repellents and as well as modifying the soil behaviour' (Zaliha et al., 2013: p. 259). The chemical reaction of soil particles and chemical additives creates a strong bond between the soil grains, resulting in a stronger, more durable and better quality soil in comparison to an untreated soil. In the case of lime, the reactions are mainly pozzolanic, and with cement, they are hydraulic. A hydraulic reaction needs only water to react and increase in strength while a pozzolanic reaction requires water and a pozzolanic material like soil (Janz and Johansson, 2002). According to several authors (Criado et al., 2007; PachecoTorgal et al., 2012), alkaline-activated materials, in general, perform better than cement from a mechanical point of view and show increased durability and stability. There are currently also many researchers and practitioners investigating soil stabilisation where triple binders are used, as in the present research where different combinations of FA and cement with sandy material are tested (AustStab, 2012).

Utilisation of FA stabilisation of the soil used in subgrade improves the stability of the working platform, which becomes less susceptible to disturbance by moisture and construction traffic (Mackiewicz and Ferguson, 2005). Subgrade soil stabilisation can save huge amounts of money by reducing the thickness of pavement layers, in comparison to traditional methods, which involve cutting out and replacing the unstable subgrade soil (Beeghly, 2003). Makusa (2012) states the following limitations that stabilised soil-FA can have.

- Soil to be stabilised may have less moisture content; therefore, dewatering may be required.

- Soil-FA mixtures cured below zero and then soaked in water are highly susceptible to slaking and strength loss.

- Sulfur content can form expansive minerals in soil-FA mixtures, which reduces long-term strength and durability.

According to Hossain (2010: p. 182), soils with a 'liquid limit less than $40 \%$ and plasticity index within the range $22-25 \%$ are most suitable for stabilization.' Nevertheless, it was concluded, by the same author, that soils could be inconsistent with these two conditions and still prove suitable for stabilisation (Hossain, 2010). Thus, investigating the stabilisation of different types and combinations of stabilisers and soil types is essential.

Makusa (2012) reports that for a given degree of compaction, the maximum dry density (MDD) is usually lower for stabilised soil than for untreated soil. Also, the optimum moisture content (OMC) increases on increasing the binders. This is believed to occur due the heat generated when the binders begin their chemical reactions. According to Makusa (2012), the hydration process in soils stabilised by cement occurs directly after water and cement come into contact. Furthermore, the author states that in stabilised soils, 'enough moisture content is essential not only for hydration process to proceed but also for efficient compaction' (Makusa, 2012: p. 11).

\subsection{Stabilisation activation}

Cement has been one of the most common stabilisers utilised throughout the past decades. One of the key factors in utilising cement in stabilising soils is that the cement reaction is independent of soil minerals and relies on the water that may be found in any soil. Soils stabilised with cement could have the following improved properties (Makusa, 2012)

- decreased cohesiveness

- decreased volume expansion or compressibility

- increased strength.

Class F FA can only be utilised in stabilisation with the addition of an activator, like cement or lime. According to Cristelo et al. (2012b), soil stabilised with cement-based binders achieved a higher mechanical strength, when compared to soil stabilised with lime-based binders. Another benefit of using cement as an activator for FA is that it can lead to lower leachate of heavy metals and/or help in containing it (Kamon et al., 2000). The US air force has developed a methodology (Figure 4), where suitable stabilisers are suggested based on soil type (Little and Nair, 2009). 


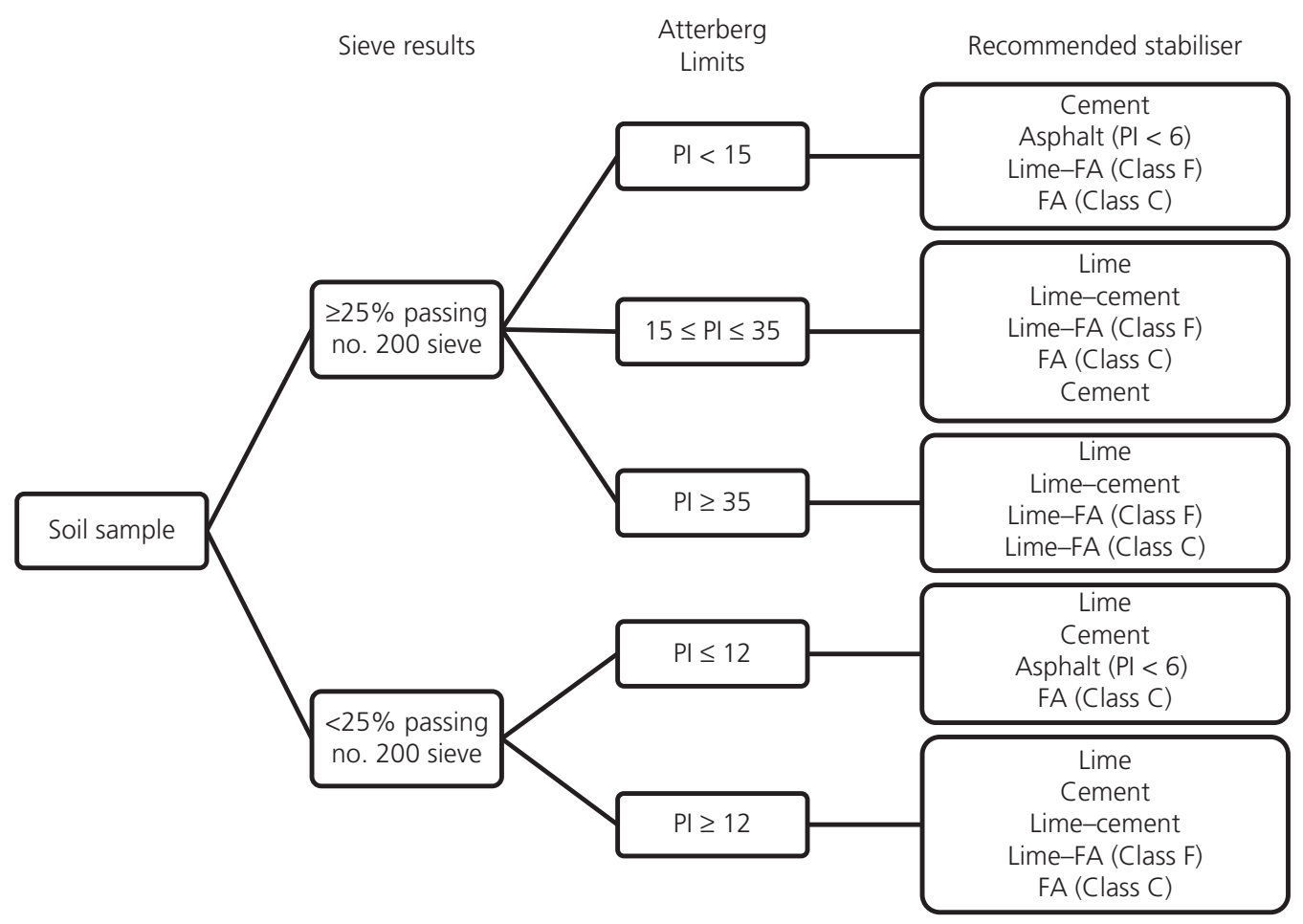

Figure 4. The decision tree of stabiliser selection (after Little and Nair, 2009)

\subsection{Laboratory testing}

An increasing amount of research resources is being directed to the study of FA utilisation and FA stabilisation. In studies where FA was utilised to stabilise soil, a series of laboratory tests have been performed. The most common of these tests are

- PSD test (Cristelo et al., 2011, 2012b)

- CBR test (Hossain, 2010; Jackson et al., 2007; Kolias et al., 2005; Sato and Nishimoto, 2005)

- CS test (Arioz et al., 2013; Cristelo et al., 2012a; Kamon et al., 2000; Kolias et al., 2005; Sato and Nishimoto, 2005)

- X-ray diffraction analysis (Arioz et al., 2013; Cristelo et al., 2012a; Kolias et al., 2005).

For the purpose of this paper, a series of PSD and CBR tests have been performed, based on previous results of compaction tests (Mahvash et al., 2017). The results of numerous tests found in the literature are summarised in Table 1. It can be seen that several researchers (Arora and Aydilek, 2005; Cristelo et al., 2011, 2012a, 2012b; Kolias et al., 2005; McCarthy et al., 2011; Reyes and Pando, 2007; Sahu, 2001; Santos et al., 2011) reviewed the effect of FA (both Classes C and $\mathrm{F}$ ) on ground improvement through soil stabilisation. This table also shows that the majority of the tested soils have been clays with few sandy samples. It can be suggested that, in general, for most of the soils, there is an increase in the CBR value after the treatment, except for one case in the study by Sahu (2001), where there was a reduction in CBR, for the Kalahari sand, from 40 to $10 \%$ when $24 \%$ FA was used, and down to $30 \%$ when $8 \%$ FA was used. In the study by Arora and Aydilek (2005), silty sand was stabilised with 40\% FA (Class F) content with two different activators, lime and cement. Over a 4 week curing period, the samples stabilised with cement achieved an unconfined compressive strength (UCS) of $5.0 \mathrm{MPa}$, over 12 times higher than what was achieved with lime. This result was consistent with the conclusion obtained by other authors, like Cristelo et al. (2012b), which also state that cement-based binders typically produce significantly better and more consistent results when compared with lime-based binders. Thus, it can be suggested that cement is a more viable option as an activator than lime.

Additionally, results by Santos et al. (2011) illustrated that there is no substantial improvement when the FA content is raised from 40 to $60 \%$, whereas there was a clear improvement with an increase from 20 to $40 \%$ of FA content. Meanwhile, Cristelo et al. (2011) published the results of extensive research on soil improvement by utilising Class F FA. The curing periods took as long as a year and produced overwhelming results, with one sample (40\% FA - $365 \mathrm{~d}$ curing) achieving $43 \mathrm{MPa}$ in UCS. In the same study, samples were also cured for 90 and $28 \mathrm{~d}$, with UCS of 17 and $8 \mathrm{MPa}(40 \% \mathrm{FA})$, respectively. Therefore, it can be suggested that the longer the curing period, the higher the strength of the soil. Furthermore, Cristelo et al. (2012a) compared stabilisation with both Class $\mathrm{C}$ and Class F FA, using the same FA content $(20 \%)$ and equal curing periods $(84 \mathrm{~d})$ and found that the Class F-stabilised samples had about three times the strength 
Table 1. Results of soil stabilising by using FA from nine different studies

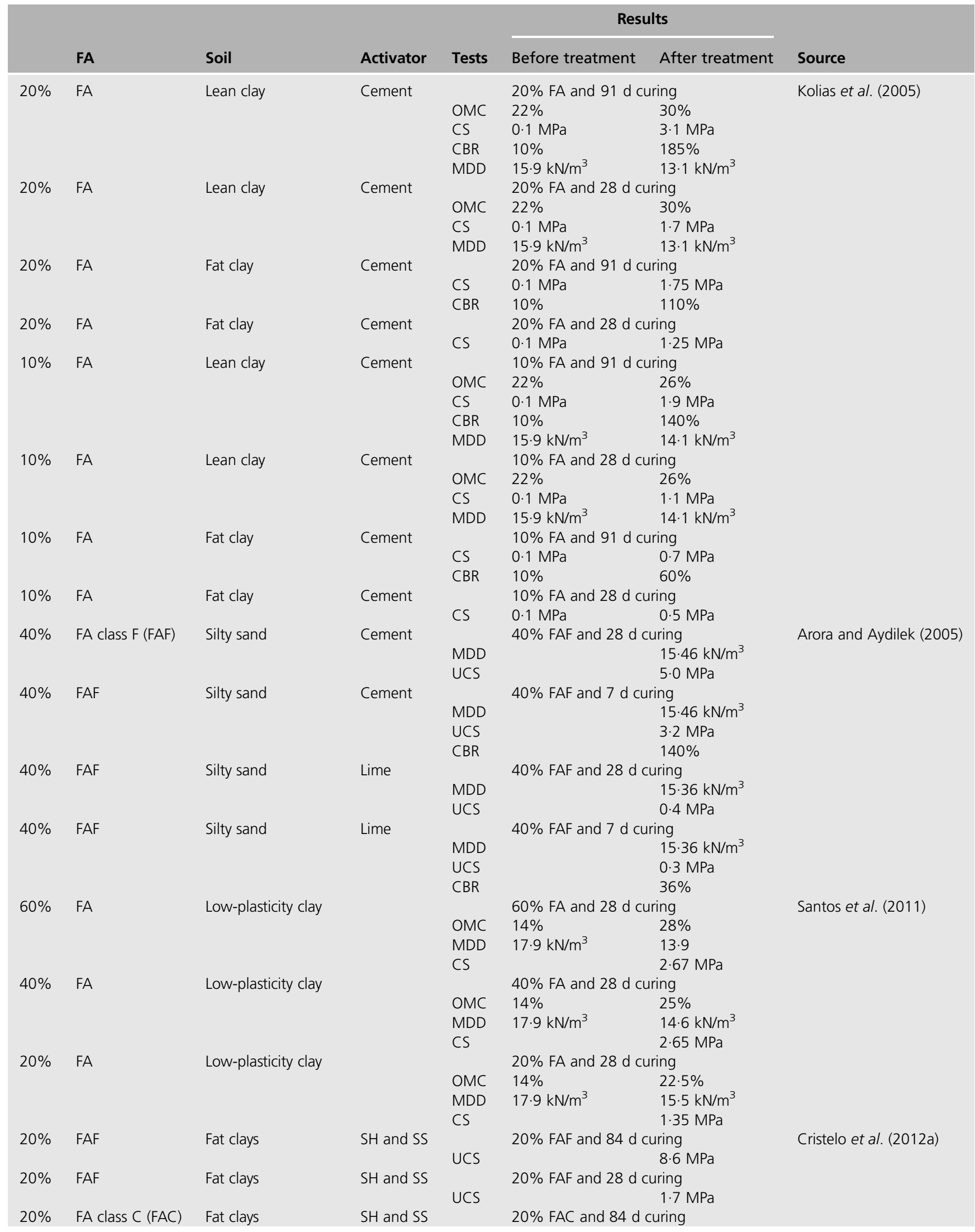




\begin{tabular}{|c|c|c|c|c|c|c|c|}
\hline & \multirow[b]{2}{*}{ FA } & \multirow[b]{2}{*}{ Soil } & \multirow[b]{2}{*}{ Activator } & \multirow[b]{2}{*}{ Tests } & \multicolumn{2}{|c|}{ Results } & \multirow[b]{2}{*}{ Source } \\
\hline & & & & & Before treatment & After treatment & \\
\hline \multirow{3}{*}{$20 \%$} & & & & UCS & & $3.0 \mathrm{MPa}$ & \\
\hline & FAC & Fat clays & SH and SS & & $20 \%$ FAC and $28 d$ & uring & \\
\hline & & & & UCS & & $1 \cdot 3 \mathrm{MPa}$ & \\
\hline \multirow[t]{2}{*}{$10 \%$} & FAF & Fat clays & SH and SS & & $10 \%$ FAF and $84 \mathrm{~d}$ & uring & \\
\hline & & & & UCS & & $4 \cdot 2 \mathrm{MPa}$ & \\
\hline \multirow[t]{2}{*}{$10 \%$} & FAF & Fat clays & SH and SS & & $10 \%$ FAF and $28 d$ & uring & \\
\hline & & & & UCS & $10 \%$ FAC and $84 \mathrm{~d}$ & $0.6 \mathrm{MPa}$ & \\
\hline $10 \%$ & FAC & rat clays & SH and SS & UCS & & $2.0 \mathrm{MPa}$ & \\
\hline \multirow[t]{2}{*}{$10 \%$} & FAC & Fat clays & SH and SS & & $10 \%$ FAC and $28 d$ & uring & \\
\hline & & & & UCS & & $1 \cdot 1 \mathrm{MPa}$ & \\
\hline \multirow[t]{2}{*}{$25 \%$} & FAF & Granitic residual soil & $\mathrm{SH}$ and SS & & $25 \%$ FAF and $7 \mathrm{~d} c$ & ing & Cristelo et al. (2012b) \\
\hline & & & & $\begin{array}{l}\text { UCS } \\
\text { MDD }\end{array}$ & $19 \cdot 2 \mathrm{kN} / \mathrm{m}^{3}$ & $17 \mathrm{MPa}$ & \\
\hline \multirow[t]{3}{*}{$20 \%$} & FAC & High-plasticity clay & & & $20 \%$ FAC and $40 \mathrm{~d}$ & uring & Reyes and Pando (2007) \\
\hline & & & & MDD & $12 \cdot 1 \mathrm{kN} / \mathrm{m}^{3}$ & & \\
\hline & & & & UCS & $0.24 \mathrm{MPa}$ & $0.96 \mathrm{MPa}$ & \\
\hline \multirow[t]{3}{*}{$20 \%$} & FAC & High-plasticity clay & & & $20 \%$ FAC and $28 d$ & uring & \\
\hline & & & & MDD & $12 \cdot 1 \mathrm{kN} / \mathrm{m}^{3}$ & & \\
\hline & & & & UCS & $0.24 \mathrm{MPa}$ & $0.9 \mathrm{MPa}$ & \\
\hline \multirow[t]{3}{*}{$10 \%$} & FAC & High-plasticity clay & & & $10 \%$ FAC and $40 \mathrm{~d}$ & uring & \\
\hline & & & & MDD & $12 \cdot 1 \mathrm{kN} / \mathrm{m}^{3}$ & & \\
\hline & & & & UCS & $0.24 \mathrm{MPa}$ & $0.56 \mathrm{MPa}$ & \\
\hline \multirow[t]{3}{*}{$10 \%$} & FAC & High-plasticity clay & & & $10 \%$ FAC and $28 d$ & uring & \\
\hline & & & & MDD & $12 \cdot 1 \mathrm{kN} / \mathrm{m}^{3}$ & & \\
\hline & & & & UCS & $0.24 \mathrm{MPa}$ & $0.45 \mathrm{MPa}$ & \\
\hline $24 \%$ & FA & Kalahari sand & & & $24 \% \mathrm{FA}$ and $7 \mathrm{~d} c u$ & & Sahu (2001) \\
\hline & & & & $\mathrm{OMC}$ & $5 \%$ & $7 \%$ & \\
\hline & & & & MDD & $17 \cdot 3 \mathrm{kN} / \mathrm{m}^{3}$ & $14.7 \mathrm{kN} / \mathrm{m}^{3}$ & \\
\hline & & & & CBR & $40 \%$ & $10 \%$ & \\
\hline $24 \%$ & FA & Concrete & & & $24 \% \mathrm{FA}$ and $7 \mathrm{~d} \mathrm{cu}$ & & \\
\hline & & & & OMC & $15 \cdot 60 \%$ & $17 \%$ & \\
\hline & & & & MDD & $17.2 \mathrm{kN} / \mathrm{m}^{3}$ & $16 \cdot 3 \mathrm{kN} / \mathrm{m}^{3}$ & \\
\hline & & & & CBR & $40 \%$ & $90 \%$ & \\
\hline $24 \%$ & FA & Silty sand & & & $24 \%$ FA and $7 \mathrm{~d} c u$ & & \\
\hline & & & & OMC & $9 \%$ & $9 \%$ & \\
\hline & & & & MDD & $19.0 \mathrm{kN} / \mathrm{m}^{3}$ & $18.2 \mathrm{kN} / \mathrm{m}^{3}$ & \\
\hline & & & & CBR & $80 \%$ & $470 \%$ & \\
\hline $24 \%$ & FA & Black cotton soil & & & $24 \% \mathrm{FA}$ and $7 \mathrm{~d} \mathrm{cu}$ & & \\
\hline & & & & OMC & $20 \%$ & $23 \cdot 50 \%$ & \\
\hline & & & & MDD & $15 \cdot 1 \mathrm{kN} / \mathrm{m}^{3}$ & $14.8 \mathrm{kN} / \mathrm{m}^{3}$ & \\
\hline & & & & CBR & $0 \%$ & $25 \%$ & \\
\hline $24 \%$ & FA & Low-plasticity silt & & & $24 \% \mathrm{FA}$ and $7 \mathrm{dcu}$ & & \\
\hline & & & & $\mathrm{OMC}$ & $12 \%$ & $12 \cdot 30 \%$ & \\
\hline & & & & MDD & $19 \cdot 8 \mathrm{kN} / \mathrm{m}^{3}$ & $18.9 \mathrm{kN} / \mathrm{m}^{3}$ & \\
\hline & & & & CBR & $10 \%$ & $230 \%$ & \\
\hline $8 \%$ & FA & Kalahari sand & & & $8 \% \mathrm{FA}$ and $7 \mathrm{~d}$ curi & & \\
\hline & & & & OMC & $5 \%$ & $5 \%$ & \\
\hline & & & & MDD & $17 \cdot 3 \mathrm{kN} / \mathrm{m}^{3}$ & $16 \cdot 8 \mathrm{kN} / \mathrm{m}^{3}$ & \\
\hline & & & & CBR & $40 \%$ & $30 \%$ & \\
\hline $8 \%$ & FA & Concrete & & & $8 \% \mathrm{FA}$ and $7 \mathrm{~d}$ curi & & \\
\hline & & & & OMC & $15 \cdot 60 \%$ & $19 \cdot 90 \%$ & \\
\hline & & & & MDD & $17 \cdot 2 \mathrm{kN} / \mathrm{m}^{3}$ & $16 \cdot 4 \mathrm{kN} / \mathrm{m}^{3}$ & \\
\hline & & & & CBR & $40 \%$ & $60 \%$ & \\
\hline $8 \%$ & FA & Silty sand & & & $8 \%$ FA and $7 d$ curi & & \\
\hline & & & & $\mathrm{OMC}$ & $9 \%$ & $8.80 \%$ & \\
\hline & & & & MDD & $19.0 \mathrm{kN} / \mathrm{m}^{3}$ & $18.6 \mathrm{kN} / \mathrm{m}^{3}$ & \\
\hline & & & & CBR & $80 \%$ & $315 \%$ & \\
\hline $8 \%$ & FA & Black cotton soil & & & $8 \%$ FA and $7 \mathrm{~d}$ curi & & \\
\hline
\end{tabular}


Table 1. Continued

\begin{tabular}{|c|c|c|c|c|c|c|c|}
\hline & \multirow[b]{2}{*}{ FA } & \multirow[b]{2}{*}{ Soil } & \multirow[b]{2}{*}{ Activator } & \multirow[b]{2}{*}{ Tests } & \multicolumn{2}{|c|}{ Results } & \multirow[b]{2}{*}{ Source } \\
\hline & & & & & Before treatment & After treatment & \\
\hline & & & & OMC & $20 \%$ & $22 \cdot 70 \%$ & \\
\hline & & & & MDD & $15 \cdot 1 \mathrm{kN} / \mathrm{m}^{3}$ & $15 \cdot 3 \mathrm{kN} / \mathrm{m}^{3}$ & \\
\hline & & & & CBR & $0 \%$ & $5 \%$ & \\
\hline \multirow[t]{4}{*}{$8 \%$} & FA & Low-plasticity silt & & & $8 \% \mathrm{FA}$ and $7 \mathrm{~d}$ curir & & \\
\hline & & & & OMC & $12 \%$ & $11.90 \%$ & \\
\hline & & & & MDD & $19 \cdot 8 \mathrm{kN} / \mathrm{m}^{3}$ & $19.6 \mathrm{kN} / \mathrm{m}^{3}$ & \\
\hline & & & & CBR & $10 \%$ & $40 \%$ & \\
\hline \multirow[t]{2}{*}{$40 \%$} & FAF & Sandy clay & SH and SS & & $40 \%$ FAF and $365 d$ & curing & Cristelo et al. (2011) \\
\hline & & & & UCS & & $43 \mathrm{MPa}$ & \\
\hline \multirow[t]{2}{*}{$40 \%$} & FAF & Sandy clay & SH and SS & & $40 \%$ FAF and $90 \mathrm{~d}$ & uring & \\
\hline & & & & UCS & & $17 \mathrm{MPa}$ & \\
\hline \multirow[t]{2}{*}{$40 \%$} & FAF & Sandy clay & SH and SS & & $40 \%$ FAF and $28 d$ & uring & \\
\hline & & & & UCS & & $8 \mathrm{MPa}$ & \\
\hline \multirow[t]{2}{*}{$20 \%$} & FAF & Sandy clay & SH and SS & & $20 \%$ FAF and $365 d$ & curing & \\
\hline & & & & UCS & & $24 \mathrm{MPa}$ & \\
\hline \multirow[t]{2}{*}{$20 \%$} & FAF & Sandy clay & SH and SS & & $20 \%$ FAF and $90 \mathrm{~d}$ & uring & \\
\hline & & & & UCS & & $5 \mathrm{MPa}$ & \\
\hline \multirow[t]{2}{*}{$20 \%$} & FAF & Sandy clay & SH and SS & & $20 \%$ FAF and $28 d$ & uring & \\
\hline & & & & UCS & & $3.5 \mathrm{MPa}$ & \\
\hline \multirow[t]{4}{*}{$24 \%$} & FA-a & Oxford clay & Lime & & $24 \% \mathrm{FA}$ and $90 \mathrm{~d} c$ & iring & McCarthy et al. (2011) \\
\hline & & & & OMC & $25 \%$ & $26 \cdot 90 \%$ & \\
\hline & & & & MDD & $14.9 \mathrm{kN} / \mathrm{m}^{3}$ & $14.3 \mathrm{kN} / \mathrm{m}^{3}$ & \\
\hline & & & & UCS & & $1.9 \mathrm{MPa}$ & \\
\hline \multirow[t]{4}{*}{$24 \%$} & $F A-b$ & Oxford clay & Lime & & $24 \% \mathrm{FA}$ and $90 \mathrm{dc}$ & Iring & \\
\hline & & & & OMC & $25 \%$ & $28 \cdot 10 \%$ & \\
\hline & & & & MDD & $14.9 \mathrm{kN} / \mathrm{m}^{3}$ & $13.7 \mathrm{kN} / \mathrm{m}^{3}$ & \\
\hline & & & & UCS & & $1.5 \mathrm{MPa}$ & \\
\hline \multirow[t]{4}{*}{$24 \%$} & FA-a & Oxford clay & Lime & & $24 \% \mathrm{FA}$ and $28 \mathrm{~d}$ & ring & \\
\hline & & & & OMC & $25 \%$ & $26 \cdot 90 \%$ & \\
\hline & & & & MDD & $14.9 \mathrm{kN} / \mathrm{m}^{3}$ & $14.3 \mathrm{kN} / \mathrm{m}^{3}$ & \\
\hline & & & & UCS & & $1.4 \mathrm{MPa}$ & \\
\hline \multirow[t]{4}{*}{$24 \%$} & $F A-b$ & Oxford clay & Lime & & $24 \% \mathrm{FA}$ and $28 \mathrm{~d}$ & ring & \\
\hline & & & & OMC & $25 \%$ & $28 \cdot 10 \%$ & \\
\hline & & & & MDD & $14.9 \mathrm{kN} / \mathrm{m}^{3}$ & $13.7 \mathrm{kN} / \mathrm{m}^{3}$ & \\
\hline & & & & UCS & & $1 \cdot 2 \mathrm{MPa}$ & \\
\hline \multirow[t]{4}{*}{$12 \%$} & FA-a & Oxford clay & Lime & & $12 \% \mathrm{FA}$ and $90 \mathrm{~d} c$ & iring & \\
\hline & & & & OMC & $25 \%$ & $26 \cdot 70 \%$ & \\
\hline & & & & MDD & $14.9 \mathrm{kN} / \mathrm{m}^{3}$ & $14.4 \mathrm{kN} / \mathrm{m}^{3}$ & \\
\hline & & & & UCS & & $1.7 \mathrm{MPa}$ & \\
\hline \multirow{4}{*}{$12 \%$} & $F A-b$ & Oxford clay & Lime & & $12 \%$ FA and $90 \mathrm{dc}$ & ring & \\
\hline & & & & OMC & $25 \%$ & $27 \cdot 40 \%$ & \\
\hline & & & & MDD & $14.9 \mathrm{kN} / \mathrm{m}^{3}$ & $14.0 \mathrm{kN} / \mathrm{m}^{3}$ & \\
\hline & & & & UCS & & $1.4 \mathrm{MPa}$ & \\
\hline $12 \%$ & FA-a & Oxford clay & Lime & & $12 \% \mathrm{FA}$ and $28 \mathrm{~d}$ & ring & \\
\hline & & & & OMC & $25 \%$ & $26 \cdot 70 \%$ & \\
\hline & & & & MDD & $14.9 \mathrm{kN} / \mathrm{m}^{3}$ & $14.4 \mathrm{kN} / \mathrm{m}^{3}$ & \\
\hline & & & & UCS & & $1 \cdot 3 \mathrm{MPa}$ & \\
\hline $12 \%$ & $F A-b$ & Oxford clay & Lime & & $12 \% \mathrm{FA}$ and $28 \mathrm{~d} c$ & ring & \\
\hline & & & & OMC & $25 \%$ & $27 \cdot 40 \%$ & \\
\hline & & & & MDD & $14.9 \mathrm{kN} / \mathrm{m}^{3}$ & $14.0 \mathrm{kN} / \mathrm{m}^{3}$ & \\
\hline & & & & UCS & & $1 \cdot 2 \mathrm{MPa}$ & \\
\hline
\end{tabular}

LL, liquid limit; ML, low-plasticity silt; CL, low-plasticity clay; MH, high-plasticity silt; CH, high-plasticity clay; SM, silty sand; SC, clayey sand; G, gravel

compared to the samples stabilised with Class C. It should be noted that there were improvements in the physical strength of FA-stabilised samples in every study. Thus, it can be concluded again that the most successful stabilisation, using Class F FA, is obtained with cement as the activator. Moreover, the curing period should be maximised. The choice of activator differs in each study. These include: cement, lime, sodium hydroxide (SH) and sodium silicate (SS). In some investigations, the 
authors used a mixture of SH and SS (Cristelo et al., 2011, 2012a, 2012b).

Figure 5 shows various possible results for soil stabilisation using FA, which have been developed from Table 1. It can be concluded that further research is required on sand, clayey sand in particular, and furthermore on high-plasticity silts. This paper focuses on sand only.

\section{Methodology}

A comprehensive series of laboratory tests consisting of PSD and CBR tests was conducted on untreated soil samples and stabilised samples using different proportions of FA and cement as the activator. Each FA content was tested with at least three samples created under the same conditions and procedures, so the results obtained could be more reliable. There were three variations of FA content chosen for this study, 5, 10 and 15\% (as in Cristelo et al., 2011, 2012a), with three different curing periods, 1, 2 and 4 weeks. In this experimental study, a total of 14 CBR tests was performed. The aim of this set of laboratory tests was to analyse the influence of FA content on the bearing capacity of the stabilised soil, by comparing stabilised soils against pre-treated samples.

Cement with a content of 3\% was chosen as activator for this study. This value was selected as an average based on previous studies (Kaniraj and Havanagi, 1999; Kolias et al., 2005). The proposed tests were performed in accordance with British standards, with at least two representative specimens for the determination of the moisture content (BSI, 1990a). It should be noted that all the samples were compacted instantly after mixing, without any delays.

\subsection{Particle size distribution}

The PSD tests performed in this study on the untreated material were in accordance with BS 1377-2:1990, classification tests, the 'dry sieving method' (BSI, 1990b: p. 36). The grading and uniformity of the soil could be evaluated using the classification graph. O'Flaherty and Hughes (2016) state that the typical values for the coefficient of curvature and coefficient of uniformity, $C_{\mathrm{c}}$ and $C_{\mathrm{u}}$, of evenly graded soil are $<1$ and $<6$, respectively. Soils with a particle size range of 0.06-2 $\mathrm{mm}$ are classified as sand according to the British soil classification system (BSI, 1990b).

\subsection{California bearing ratio}

As is well known, the CBR is obtained by measuring the relationship between force and penetration when a cylindrical plunger is made to penetrate the soil at a standard rate. In order to find the optimal values, the CBR tests were carried out in accordance with BS 1377-4:1990, 'Determination of the California Bearing Ratio' (BSI, 1990c: p. 30). A series of

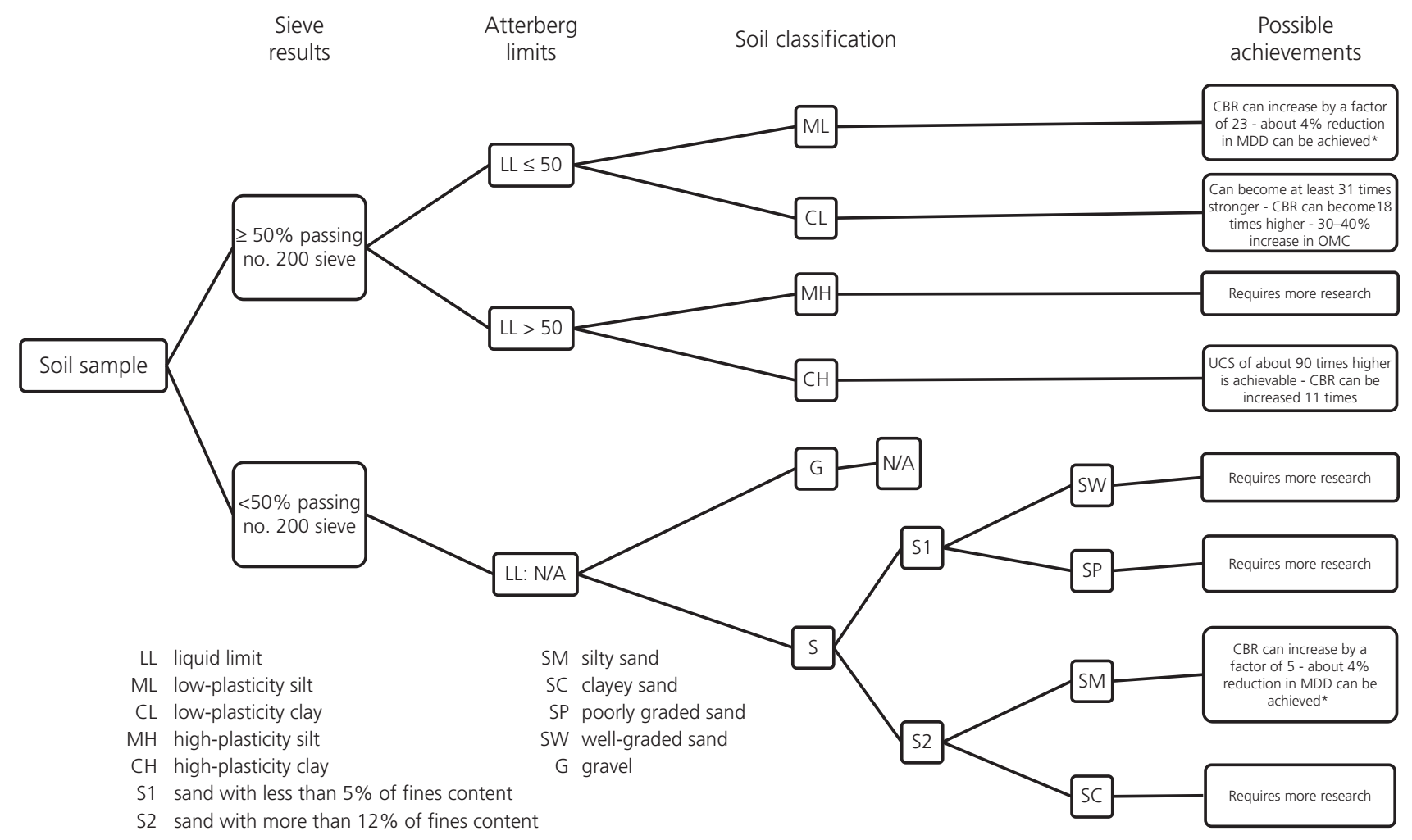

Figure 5. Various possible results of soil stabilisation using FA. Note: These results are possible with curing during 12-13 weeks with FA content of $20-24 \%$. *Cured for only $7 d$ 
compaction tests (Proctor) was carried out first, to identify the optimal water content for each FA content, and therefore all the CBR samples were compacted under optimal conditions (Mahvash et al., 2017). The CBR tests were carried out in a modified CBR mould with soil compacted in three layers and each layer was subjected to 72 blows from the $2.5 \mathrm{~kg}$ rammer (BSI, 1990c). A surcharge of $2 \mathrm{~kg}$ was also used in the CBR tests. All the samples were mixed, compacted and sealed within $30 \mathrm{~min}$. During the curing, the temperature remained constant at around $21{ }^{\circ} \mathrm{C}$ throughout. The samples were stored in airtight bags during the curing period to keep their humidity constant.

\subsection{Resilience modulus and UCS by correlation}

The American Association of State Highway and Transportation Officials (Aashto) now favours the resilient modulus dynamic stiffness test for characterising the strength of pavement material (Beeghly, 2003). The resilient modulus $\left(M_{\mathrm{r}}\right)$ is the elastic modulus utilised in mechanistic-empirical pavement analyses and design (Lav and Lav, 2014). According to O'Flaherty and Hughes (2016), $M_{\mathrm{r}}$ is the fundamental subgrade strength parameter needed as input to any rational or mechanistic pavement design process (O'Flaherty and Hughes, 2016). For the purpose of this study, the correlation (Equation 1) derived by the Transportation and Road Research Laboratory is used to evaluate $M_{\mathrm{r}}$ values (in $\mathrm{kN} / \mathrm{m}^{2}$ ) in correlation with the obtained CBR values (Buchanan, 2007; Coleri, 2007)

\section{1. $M_{\mathrm{r}}=17616 \cdot 1 \mathrm{CBR}^{0.64}$}

Furthermore, another common factor in the road design process is the UCS. A study by Behera and Mishara (2012) was carried out to correlate the CBR and the UCS (in MPa) in a FA-lime mixture at 7 and $28 \mathrm{~d}$ curing periods (Behera and Mishara, 2012, cited by Purwana and Nikraz, 2014). Based on that, the following equations have been derived to evaluate UCS values (in MPa), using the achieved CBR values

2. $7 \mathrm{~d} \mathrm{UCS}=(\mathrm{CBR}-14 \cdot 14) / 108 \cdot 8$

3. $14 \mathrm{~d} \mathrm{UCS}=(\mathrm{CBR}-26 \cdot 63) / 82.63$

4. $28 \mathrm{~d} \mathrm{UCS}=(\mathrm{CBR}-39 \cdot 13) / 56 \cdot 45$

\section{Materials}

4.1 Sand

For the purpose of this study, sand (building sand) was obtained from Civils \& Lintels, a UK supplier. The sand was delivered in polyethylene bags of $25 \mathrm{~kg}$. The sand had an MDD of $1741 \mathrm{~kg} / \mathrm{m}^{3}$ and OMC of $13 \cdot 4 \%$ in its original state.

\subsection{Fly ash}

The FA utilised in this study was obtained from Ratcliffe-onSoar power station in Nottingham, UK (Omni-Cem, 2011, unpublished). According to ASTM, Class F FAs contain at least $70 \%$ by weight of silicon dioxide $\left(\mathrm{SiO}_{2}\right)+$ aluminium oxide $\left(\mathrm{Al}_{2} \mathrm{O}_{3}\right)+$ iron oxide $\left(\mathrm{Fe}_{2} \mathrm{O}_{3}\right)($ Kelly, 2015). The FA used in this study contained nearly $75 \%$ by weight of silicon dioxide + aluminium oxide + iron oxide. Thus, the FA in this research can be classified as Class F.

In order to produce more consistent samples, the irregular and larger particles in the FA had to be removed. The FA was oven dried and then passed through a $2.36 \mathrm{~mm}$ sieve. Over $20 \%$ of the total FA, as supplied, was $>2 \cdot 36 \mathrm{~mm}$.

\subsection{Cement}

The cement used in this study was ordinary Portland cement, obtained from a UK supplier. The following conditions were obtained from the manufacturer's data sheet (Lafarge, 2012)

- based on sustainable cement technology

- consistent strength meeting all the conformity criteria in BS EN 197-1 (BSI, 2011)

- manufactured from natural products.

\section{Results and discussion}

After the analysis of the PSD for the soil (Figure 6), the coefficients of the sand were evaluated, with a $C_{\mathrm{u}}$ value of about 2 and $C_{\mathrm{c}}$ value of just under $1(0 \cdot 98)$. This would classify the soil as a poorly and/or evenly graded soil (O'Flaherty and Hughes, 2016). It can also be seen from Figure 6 that the soil would classify as sand according to British standards (BSI, 1990b). A similar evaluation process proved that the FA had a grain size similar to that of silt and/or clay (Figure 7).

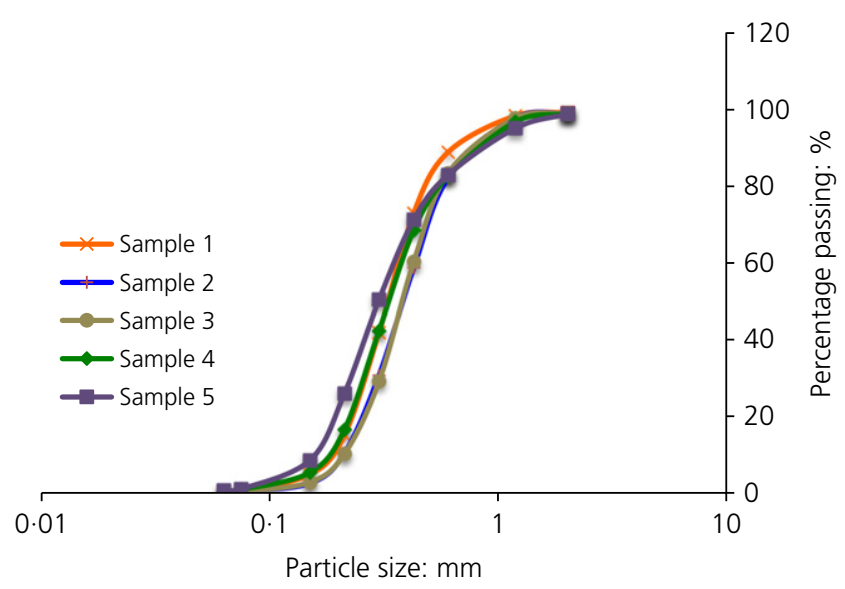

Figure 6. PSD of five samples of sand 


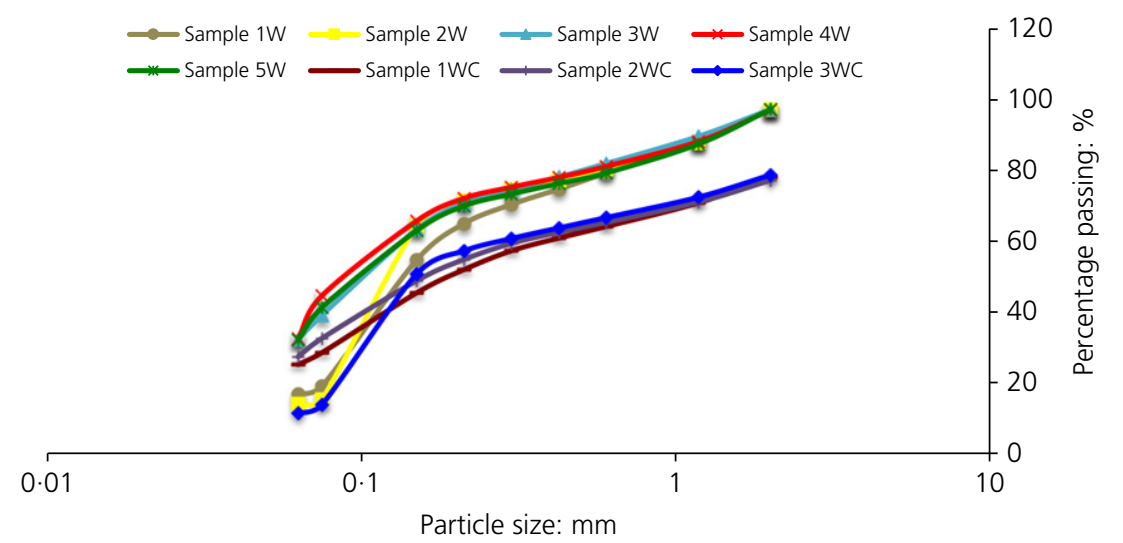

Figure 7. PSD test of five samples of FA without coarse content (W) and PSD test of three samples of FA with coarse content (WC)

Table 2. CBR, UCS and the $M_{\mathrm{r}}$ values of all the stabilised samples

\begin{tabular}{llcccc} 
Sample & Code & Curing period: $\mathbf{d}$ & CBR: $\%$ & UCS: MPa & $\mathbf{M}_{\mathbf{r}}: \mathbf{M P a}$ \\
\hline Sand & S-OC-OFA & 0 & $18 \cdot 03$ & $0 \cdot 04$ & $112 \cdot 1$ \\
Sand+3\% cement & S-3C-OFA7 & 7 & $41 \cdot 43$ & $0 \cdot 25$ & $191 \cdot 0$ \\
Sand+3\% cement & S-3C-0FA14 & 14 & $61 \cdot 7$ & $0 \cdot 42$ & $246 \cdot 4$ \\
Sand+3\% cement & S-3C-0FA28 & 28 & $66 \cdot 18$ & $0 \cdot 48$ & $257 \cdot 7$ \\
Sand+5\% cement & S-5C-OFA & 7 & $96 \cdot 53$ & $0 \cdot 76$ & $328 \cdot 2$ \\
Sand+3\% cement+5\% FA & S-3C-5FA7 & 7 & $31 \cdot 82$ & $0 \cdot 16$ & $161 \cdot 3$ \\
Sand+3\% cement+5\% FA & S-3C-5FA14 & 14 & $42 \cdot 36$ & $0 \cdot 19$ & $193 \cdot 7$ \\
Sand+3\% cement+5\% FA & S-3C-5FA28 & 28 & $53 \cdot 94$ & $0 \cdot 22$ & $226 \cdot 1$ \\
Sand+5\% cement+5\% FA & S-5C-5FA7 & 7 & $120 \cdot 03$ & $0 \cdot 97$ & $377 \cdot 3$ \\
Sand+3\% cement+10\% FA & S-3C-10FA7 & 7 & $25 \cdot 7$ & $0 \cdot 11$ & $140 \cdot 7$ \\
Sand+3\% cement+10\% FA & S-3C-10FA14 & 14 & $47 \cdot 43$ & $0 \cdot 25$ & $208 \cdot 2$ \\
Sand+3\% cement+10\% FA & S-3C-10FA28 & 28 & $59 \cdot 5$ & $0 \cdot 36$ & $240 \cdot 8$ \\
Sand+5\% cement+10\% FA & S-5C-10FA7 & 7 & $136 \cdot 9$ & $1 \cdot 13$ & $410 \cdot 4$ \\
Sand+5\% cement+10\% FA & S-5C-10FA14 & 14 & $156 \cdot 7$ & $1 \cdot 57$ & $447 \cdot 5$ \\
Sand+5\% cement+10\% FA & S-5C-10FA28 & 28 & $262 \cdot 01$ & $3 \cdot 95$ & $621 \cdot 8$ \\
Sand+3\% cement+15\% FA & S-3C-15FA7 & 7 & $33 \cdot 08$ & $0 \cdot 17$ & $165 \cdot 4$ \\
Sand+3\% cement+15\% FA & S-3C-15FA14 & 14 & $55 \cdot 27$ & $0 \cdot 37$ & $229 \cdot 7$ \\
Sand+3\% cement+15\% FA & S-3C-15FA28 & 28 & $66 \cdot 95$ & $0 \cdot 49$ & $259 \cdot 7$ \\
Sand+5\% cement+20\% FA & S-5C-20FA & 7 & $198 \cdot 54$ & $1 \cdot 69$ & $520 \cdot 6$
\end{tabular}

${ }^{\mathrm{a} A f t e r}$ Wood (2016)

The results of CBR tests performed with different FA content, different curing periods and cement content are presented in this section and discussed further. The results of all the CBR tests performed for this study are tabulated in Table 2, where the denomination for each case is also presented. It can be seen that the CBR values of all the stabilised samples were increased in comparison to sand-only (S-0C-0FA), by a range of $76-1453 \%$. The CBR test results achieved for each sample showed the mechanical strength of the material under each condition.

Figure 8 demonstrates the effect of cement content on the CBR values. The untreated sand sample had an average CBR value of $18 \%$ for the three samples. The results of the study show that the influence of the addition of cement on the mechanical strength of cement-only-stabilised samples is significant, multiplying the CBR value by a minimum factor of 2 . The highest strength gained was in the 1 week cured sample of $5 \%$ cement and no FA (S-5C-0FA), achieving an improvement in CBR value of $96.53 \%$. The tests established that the percentage of cement positively increased the strength of the material dramatically, while the curing period (using 3\% cement) had a smaller yet still positive impact on the materials' strength.

Observing the CBR values of samples S-3C-0FA and S-5C0FA, it can be seen that the CBR value was increased from 41.43 to $96.53 \%$ by the addition of $2 \%$ of cement. Meanwhile, the initial $3 \%$ addition of cement to the S-0C-0FA sample improved the CBR value by $23 \cdot 4 \%$. Clearly, the chemical reactions between this particular sand and the cement have proved to be profound. The results show that the use of cement in the stabilised mix has played a major role in the improvement of the CBR values achieved. In this study, the addition of cement was only for activation purposes. However, Kolias et al. (2005) also presented a similar observation, where samples with $4 \%$ 


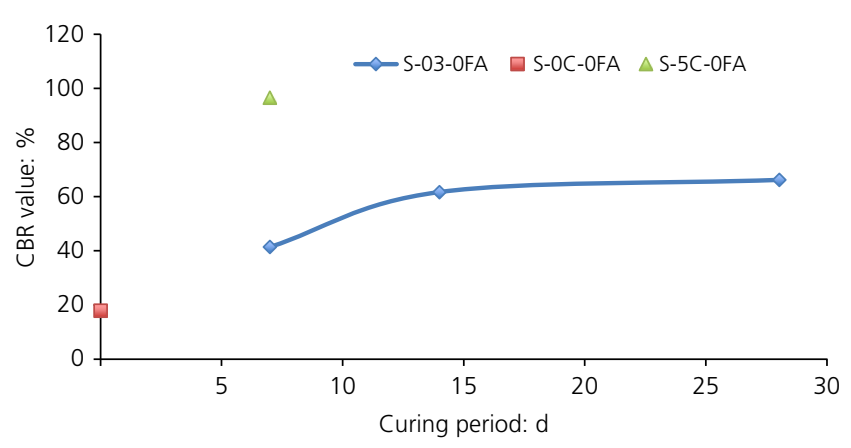

Figure 8. Effect of cement content on the CBR values of untreated sand and sand + cement

cement content ( $5 \%$ FA content) proved to be much more viable than $2 \%$ cement content samples, where there was no significant improvement post $14 \mathrm{~d}$ of curing. If the cementonly samples (in Figure 8 and S-3C-0FA7, S-3C-0FA14 and S-3C-0FA28 in Figure 9 for $0 \%$ of FA) were isolated, it is evident that for increasing curing periods the $\mathrm{CBR}$ values would increase without the FA, reaching almost the maximum expected level of bearing capacity after $28 \mathrm{~d}$ of curing. Similar behaviour was also observed in previous studies (Kolias et al., 2005; Sahu, 2001).

Moreover, Figure 9 illustrates how the FA percentage affects the achievable bearing capacity of the stabilised soil. To analyse the effect of FA content, the samples with a mixture of 3\% cement addition are presented in this figure. The graph also shows the CBR values of samples with no addition of FA, so that the effect of FA can be observed more accurately as, by keeping the cement content constant, the FA content is the only variable affecting the possible strength achieved. It can be seen that there is a reduction in CBR values, with respect to $0 \%$ of $\mathrm{FA}$, as $5 \%$ FA is added to the cement-only samples for 2 and 4 weeks of curing, while the reduction reaches its minimum for $10 \%$ of FA after 1 week of curing. For a higher FA content (i.e. 15\%), CBR values seem to have an increasing trend.

Figure 10 presents the effect of the curing period on CBR values for the whole set of samples. As can be seen, the samples stabilised with $3 \%$ cement have all produced a similar

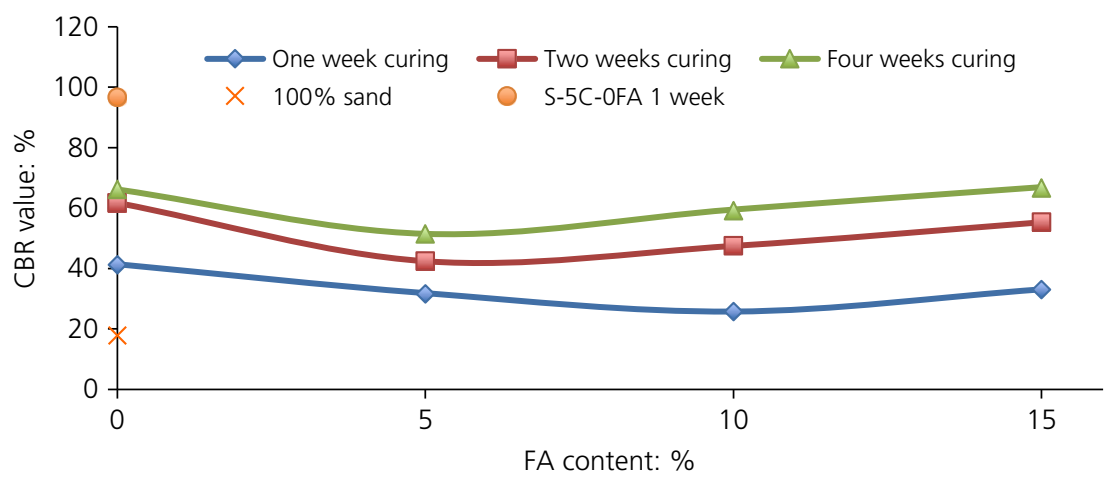

Figure 9. Effect of FA content of CBR values (3\% of cement, except the result for $100 \%$ sand)

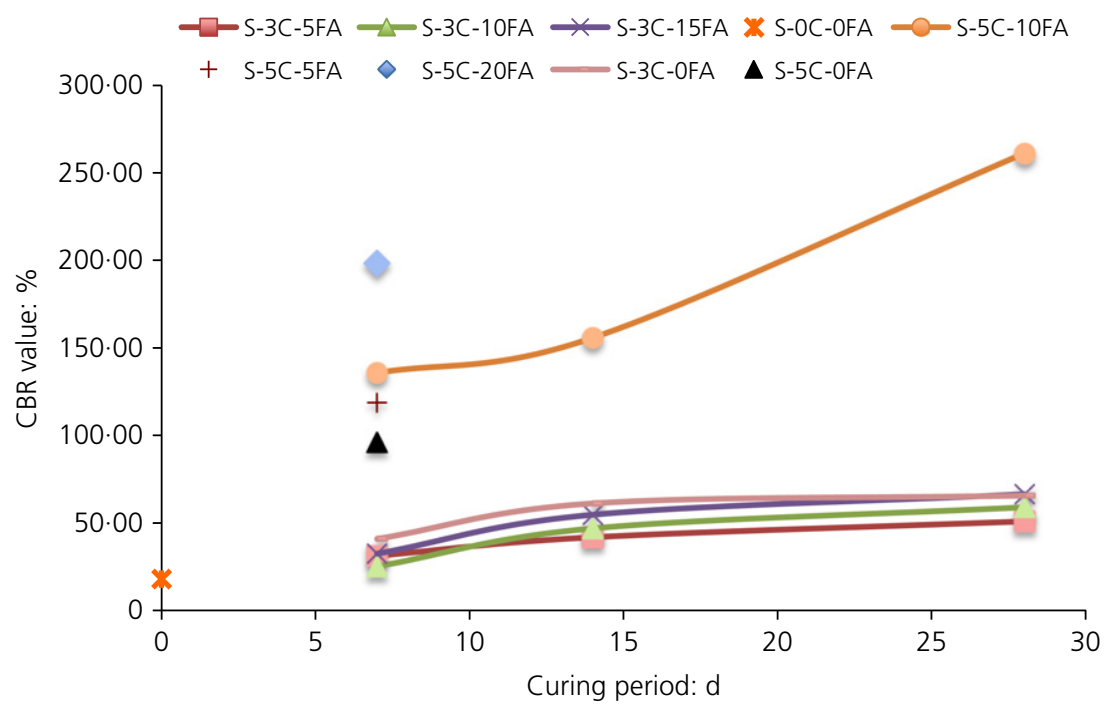

Figure 10. Effect of curing periods on CBR values 


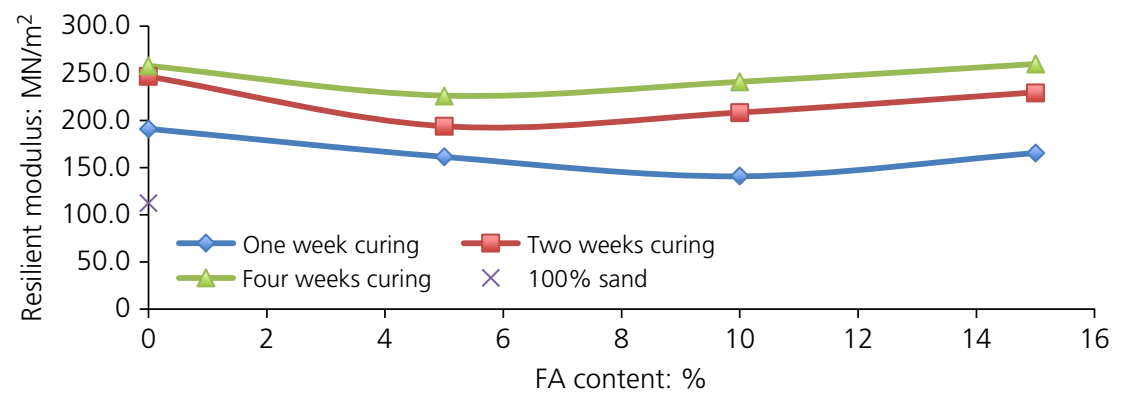

Figure 11. Effect of FA content on resilient modulus

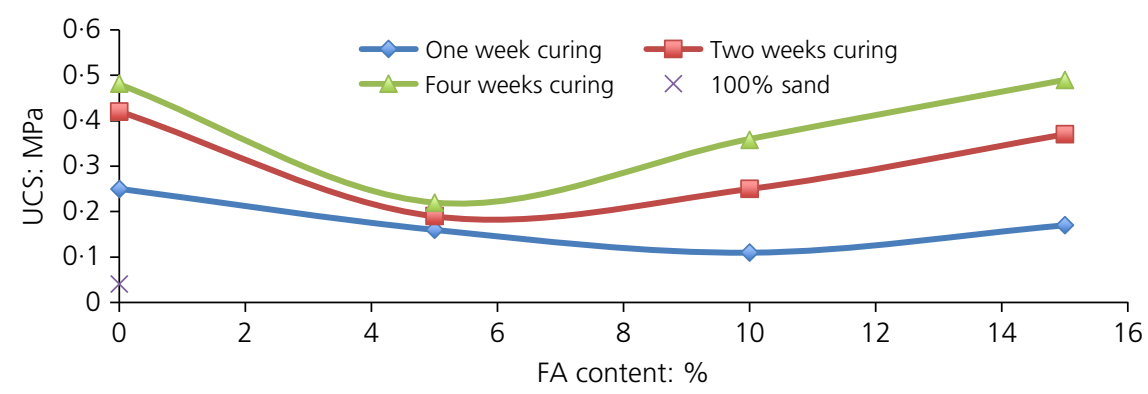

Figure 12. Effect of FA content on UCS

overall trend, with an increase in CBR values as the curing periods are extended. By keeping the FA and cement content constant, the only variable between the samples is the curing time. Tests were carried out for curing periods of 1, 2 and 4 weeks. It is also remarkable that all the results of CBR obtained for $0 \%$ of FA and 3\% of cement follow the same discussed trend, and are higher than those obtained for the different tested amounts of FA, although after 4 weeks of curing the CBR values are very similar to those for $15 \%$ of FA, whereas for 5 and $10 \%$ these values keep the same increasing trend. For comparison, previous results obtained for the same material, using $5 \%$ of cement and $10 \%$ of FA, are also presented (Wood, 2016). From these results, it is clear that the effect of a higher proportion of cement on the bearing capacity is quite remarkable, with an increasing trend with the curing time far from achieving an asymptotic value after the 4 weeks of curing, while for $3 \%$ of cement, the results do not seem to indicate the same steep increasing trend for week 4 as for $5 \%$ of cement, but a much more moderate one, indicating that the activation reactions are almost complete after $28 \mathrm{~d}$ for $3 \%$ of cement.

Figure 10 clearly shows the improvement in CBR values as an effect of a longer curing time in all cases. The FA samples with $3 \%$ cement content exhibit CBR values in the range of 25.7-66.95\% with a slight upward correlation between all, proving that as curing time was increased so did the strength of the sample. The strongest sample was the 4 weeks, $10 \%$ FA and $5 \%$ cement, achieving a CBR value of more than 14.5 times the CBR achieved in the sand in its original state.
As presented in Table 2, the values of UCS and $M_{\mathrm{r}}$ were predicted using the correlations stated earlier. It should be highlighted that these correlations are not intended to yield very accurate results for these magnitudes, but at the same time, a possible range of values can be obtained from them that would have been obtained through laboratory tests. Figures 11 and 12, which illustrate the relationship between FA content and the $M_{\mathrm{r}}$ and UCS, were derived from these values. It can be seen that in both figures, all the different curing periods have produced the same behaviour and are correlated with each other. The highest UCS value obtained was for the S-3C-15FA28 sample, with a value of $0.49 \mathrm{MPa}$, achieving an improvement of over 12 times compared to the untreated sample. As included earlier in Table 1, the UCS results of several studies concerning FA-soil stabilisation were discussed. In most of the cases, the UCS was increased by at least a factor of 4 over a $7 \mathrm{~d}$ curing period. Despite the improved UCS values with FA stabilisation, cement-only (3\% content) stabilised samples produced even higher UCS values in comparison to samples stabilised with $3 \%$ cement. The results obtained for UCS are in the same range as those reported by previous experimental research (Rezagholilou and Nikraz, 2015).

\section{Conclusions}

The main findings from the testing carried out in this research were that, as expected, the bearing capacity, measured by means of the CBR value, is very much affected by the FA percentage and curing time. However, it should be pointed out that for all the samples with $3 \%$ cement, the cement-only tests achieved higher CBR values than for the ones with additional 
5, 10 and $15 \%$ FA content, for all three different curing times. The sample S-3C-15FA28 is the only variation, which obtained a marginally higher CBR than its equivalent cement-only sample (S-3C-0FA28), by $0 \cdot 77 \%$ only, showing that the curing period of $28 \mathrm{~d}$, with $15 \%$ FA content, has a positive effect regarding bearing capacity, comparable to the $3 \%$ cement and $0 \%$ FA results. Nevertheless, based on the results of this study, this particular Class F FA and the sandy soil appear to react in a more significant manner as the cement percentage is increased, achieving higher CBR values with strong correlations with the FA content and curing period. This behaviour was also seen in testing performed in previous studies and was similar to the effects of FA content on clayey soils.

Further analysis should be carried out with different soil types to see how the soil affects the achievable strength of that sample, particularly clayey sands, as very few research studies have been found in the literature for this kind of soil.

As a result of testing, it has been proved that there is a potential application for FA to be used successfully as a soil stabiliser, with an accurate addition of cement. It increases the physical characteristics and reduces the environmental burden of current solutions. Results show how much strength increase is achievable for sandy soils, and with more analysis, it could be used for practical applications. This has the potential to be a sustainable use of the by-product of coal power stations. It can potentially provide a solution for energy companies to reduce landfill costs, and with the ever-increasing cost of landfills, could prove hugely beneficial financially.

More research should cover the topic of the variation in the results between tests in the field and laboratory tests. Having researched the literature, the approach to closing this gap is to leave the sample for $1-2 \mathrm{~h}$ after mixing to replicate the conditions on site. This, however, does not seem to be an accurate and engineered approach and should be reassessed to dictate a more specific approach to the engineering practice.

\section{REFERENCES}

Abmaruzzaman M (2010) A review on the utilisation of fly ash. Progress in Energy and Combustion Science 36(3): 327-363. ACAA (American Coal Ash Association) (2014) Beneficial Use of Coal Combustion Products: An American Recycling Success Story. ACAA, Farmington Hills, MI, USA. See http://perma.cc/ N6HM-L6T3 (accessed 20/09/2016).

Arioz E, Arioz O and Kockar O (2013) Mechanical and microstructural properties of fly ash based geopolymers. International Journal of Chemical Engineering and Applications 4(6): 397-400.

Arora S and Aydilek AH (2005) Class F fly ash amended soils as highway base materials. Journal of Materials in Civil Engineering, ASCE 17(6): 640-649.

AustStab (2012) AustStab Technical Note: Cement Stabilisation Practice. AustStab: Pavement Recycling and Stabilisation Association, Cherrybrook, Australia.

Barnes DI and Sear LKA (2006) Ash Utilisation from Coal-Based Power Plants. United Kingdom Quality Ash Association, Wolverhampton, UK.
Baykal G, Edincliler A and Saygili A (2004) Highway embankment construction using fly ash in cold regions. Resources, Conservation and Recycling 42(3): 209-222.

Beeghly JH (2003) Recent experiences with lime-fly ash stabilization of pavement subgrade soils, base, and recycled asphalt. Proceedings of the International Ash Utilization Symposium. Center for Applied Energy Research, University of Kentucky, Lexington, KY, USA, paper 46.

Bergado D, AndersIn L, Miura N and Balasubramaniam A (1996) Soft Ground Improvement: In Lowland and Other Environment. American Society of Civil Engineers, New York, NY, USA.

BSI (1990a) BS 1377-1: Methods of test for soils for civil engineering purposes: general requirements and sample preparation. BSI, London, UK.

BSI (1990b) BS 1377-2: Methods of test for soils for civil engineering purposes: classification tests. BSI, London, UK.

BSI (1990c) BS 1377-4: Methods of test for soils for civil engineering purposes: compaction-related tests. BSI, London, UK.

BSI (2011) BS 197-1: Cement. Composition, specifications and conformity criteria for common cements. BSI, London, UK.

Buchanan S (2007) Resilient Modulus: What, Why and How? Vulcan Materials Company, Birmingham, AL, USA.

Carroll RA (2015) Coal combustion products in the United Kingdom and the potential of stockpile ash. Proceedings of World of Coal Ash, Nashville, TN, USA.

Celauro B, Bevilacqua A, Lo Bosco D and Celauro C (2012) Design procedures for soil-lime stabilization for road and railway embankments. Part 1 - review of design methods. ProcediaSocial and Behavioral Sciences 53: 754-763, https://doi.org/10. 1016/j.sbspro.2012.09.925.

Cetin B and Aydilek AH (2013) $\mathrm{pH}$ and fly ash type effect on trace metal leaching from embankment soils. Resources, Conservation and Recycling 80: 107-117, https://doi.org/10.1016/j.resconrec. 2013.09.006.

Cofra (2005) Ground Improvement, MebraDrain, BeauDrain and AuGeo. Cofra, Amsterdam, the Netherlands. See http://perma.cc/ XJJ3-QP3M (accessed 10/03/2016).

Coleri E (2007) Relationship between Resilient Modulus and Soil Index: Properties of Unbound Materials. Thesis, Middle East Technical University, Ankara, Turkey.

Criado $M$, Fernàndez-Jimènez $A$, Torre $A G$, Aranda MAG and Palomo $A$ (2007) An XRD study of the effect of $\mathrm{SiO}_{2} / \mathrm{Na}_{2} \mathrm{O}$ ratio on the alkali activation of fly ash. Cement and Concrete Research 37(5): 671-667.

Cristelo N, Glendinning S and Pinto AT (2011) Deep soft soil improvement by alkaline activation. Proceedings of the Institution of Civil Engineers - Ground Improvement 164(2): 73-82, https://doi.org/10.1680/grim.900032.

Cristelo N, Glendinning S, Fernandes L and Pinto AT (2012a) Effect of calcium content on soil stabilisation with alkaline activation. Construction and Building Materials 29: 167-174, https://doi.org/ 10.1016/j.conbuildmat.2011.10.049.

Cristelo N, Glendinning S, Miranda T, Oliveria D and Silva R (2012b) Soil stabilisation using alkaline activation of fly ash for self compacting rammer earth construction. Construction and Building Materials 36: 727-735, https://doi.org/10.1016/j.conbuildmat.2012.06.037.

Cristelo N, Glendinning S, Fernandes L and Pinto AT (2013) Effects of alkaline-activated fly ash and Portland cement on soft soil stabilisation. Acta Geotechnica 8(4): 395-405.

Dockter BA, Eylands KE and Hamre LL (1999) Use of bottom ash and fly ash in rammed-earth construction. Proceedings of International Ash Utilization Symposium. Center for Applied Energy Research, University of Kentucky, Lexington, KY, USA, paper 56.

Eijk RJV, Winkel HT and Stam AF (2011) Environmental and health aspects of coal and biomass co-combustion ashes. Proceedings of World of Coal Ash, Denver, CO, USA. 
Essler R (2012) Design principles for ground improvement. In ICE Manual of Geotechnical Engineering: Volume II Geotechnical Design, Construction and Verification (Burland J, Chapman T, Skinner H and Brown M (eds)). ICE Publishing, London, UK, pp. 911-938.

Fauzi A, Nazmi WM and Fauzi UJ (2010) Subgrade stabilization of Kuantan Clay using fly ash and bottom ash. Proceedings of the 8th International Conference on Geotechnical and Transportation Engineering. GeoTropico, Bogota, Colombia.

Hossain K (2010) Development of stabilised soils for construction application. Proceedings of the Institution of Civil Engineers Ground Improvement 163(3): 173-185, https://doi.org/10.1680/ grim.2010.163.3.173 .

Jackson NM, Mack R, Schultz S and Malek M (2007) Pavement subgrade stabilization and construction using bed and fly ash. Proceedings of World of Coal Ash, Covington, KY, USA.

Janz M and Johansson SE (2002) The Function of Different Binding Agents in Deep Stabilization. Swedish Deep Stabilization Research Center, Linkoping, Sweden, Report 9.

Kamon M, Katsumi T and Sano Y (2000) MSW fly ash stabilized with coal ash for geotechnical application. Journal of Hazardous Materials 76(2-3): 265-283.

Kaniraj S and Havanagi V (1999) Compressive strength of cement stabilized fly ash-soil mixtures. Cement and Concrete Research 29(5): 673-677.

Kelly RP (2015) Parallel and nonconformities in worldwide fly ash classification: the need for a robust, universal classification system for fly ash. Proceedings of World of Coal Ash, WOCA Conference, Nashville, TN, USA.

Kolias S, Kasselouri-Rigopoulou V and Karahalios A (2005) Stabilisation of clayey soils with high calcium fly ash cement. Cement \& Concrete Composites 27(2): 301-313.

Lafarge (2012) Lafarge General Purpose Cement: A Cem II Portland-Composite Cement Suitable for Most General Purpose Applications. Lafarge, Birmingham, UK.

Lav MA and Lav AH (2014) Effects of stabilization on resilient characteristics of fly ash as pavement material. Construction and Building Materials 54: 10-16, https://doi.org/10.1016/ j.conbuildmat.2013.12.029.

Little ND and Nair S (2009) Recommended Practice for Stabilization of Subgrade Soils and Base Materials. Texas Transportation Institute, Texas A\&M University, College Station, TX, USA, National Cooperative Highway Research Program.

Mackiewicz SM and Ferguson EG (2005) Stabilizing of soil with self-cementing coal ashes. Proceedings of World of Coal Ash, Lexington, KY, USA.

Mahvash S, Lopez-Querol S and Bahadori-Jahromi A (2017) Effect of Class F fly ash on fine sand compaction through soil stabilization. Heliyon 3(3): e00274.

Makusa GP (2012) Soil Stabilization Methods and Materials. $\mathrm{PhD}$ thesis, Luleå University of Technology, Luleå, Sweden.

Manceau S, Macdiarmid C and Horgan G (2012) Design of soil reinforced slopes and structures. In ICE Manual of Geotechnical Engineering: Volume II Geotechnical Design, Construction and Verification (Burland J, Chapman T, Skinner H and Brown M (eds)). ICE Publishing, London, UK, pp. 1093-1107.

McCarthy MJ, Csetenyi JL, Jones MR and Sachdeva A (2011) Clay-lime stabilization: characterizing fly ash effects in minimizing the risk of sulphate heave. Proceedings of World of Coal Ash, WOCA Conference, Denver, CO, USA.

O'Flaherty C and Hughes D (2016) Highways: The Location, Design, Construction and Maintenance of Road Pavements, 5th edn. ICE Publishing, London, UK.

Pacheco-Torgal F, Abdollahnejad Z, Camoes AF, Jamshidi M and Diny $Y$ (2012) Durability of alkali-activated binders: a clear advantage over Portland cement or an unproven issue? Construction and
Building Materials 30: 400-405, https://doi.org/10.1016/ j.conbuildmat.2011.12.017.

Pandey VC and Singh N (2010) Impact of fly ash incorporation in soil systems. Agriculture, Ecosystems \& Environment 136(1-2): 16-27.

Porbaha A and Hanzawa H (2001) Ground modification by vertical fly ash columns. Proceedings of the Institution of Civil Engineers Ground Improvement 5(3): 101-105, https://doi.org/10.1680/ grim.2001.5.3.101

Prabakar J, Dendorkar N and Morchhale RK (2004) Influence of fly ash on strength behaviour of typical soils. Construction and Building Materials 18(4): 263-276.

Purwana MY and Nikraz H (2014) The correlation between CBR and shear strength in unsaturated soil conditions. International Journal of Transportation Engineering 1(3): 211-222.

Reyes A and Pando M (2007) Evaluation of CFBC fly ash for improvement of soft clays. Proceedings of World of Coal Ash, Covington, KY, USA.

Rezagholilou A and Nikraz H (2015) Theoretical challenges of cement modified crushed rock base material in pavements. International Journal of Research in Engineering and Advanced Technology 3(1): $38-55$.

Sahu BK (2001) Improvement in California bearing ratio of various soils in Botswana by fly ash. Proceedings of International Ash Utilization Symposium. University of Kentucky, Lexington, KY, USA, paper 90.

Santos F, Li L, Li Y and Amini F (2011) Geotechnical properties of fly ash and soil mixtures for use in highway embankments. Proceedings of World of Coal Ash, Denver, CO, USA.

Sato A and Nishimoto S (2005) Effective reuse of coal ash as civil engineering material. Proceedings of World of Coal Ash, Lexington, $K Y, U S A$.

Senol A, Edil TB, Bin-Shafique MS, Acosta $\mathrm{H}$ and Benson CH (2006) Soft subgrades stabilization by using various fly ashes. Journal of Resources, Conservation and Recycling 46(4): 365-376.

Serridge $\mathrm{CJ}$ and Slocombe B (2012) Ground improvement. In ICE Manual of Geotechnical Engineering: Volume II Geotechnical Design, Construction and Verification (Burland J, Chapman T, Skinner $\mathrm{H}$ and Brown M (eds)). ICE Publishing, London, UK, Ch. 84, pp. 1247-1269.

UKQAA (United Kingdom Quality Ash Association) (2016) UKQAA Ash Availability Report. UKQAA, Wolverhampton, UK. See http://perma.cc/65QT-S4VE (accessed 05/04/2016).

Wood J (2016) The Utilisation of Class F Fly Ash for Ground Improvement of Sand. University of West London, London, UK, final year project PowerPoint presentation.

Zaliha SZS, Kamarudin H, Al Bakri AM, Binhussain M and Salwa MSS (2013) Review on soil stabilization techniques. Australian Journal of Basic and Applied Sciences 7(5): 258-265.

\section{How can you contribute?}

To discuss this paper, please email up to 500 words to the editor at journals@ice.org.uk. Your contribution will be forwarded to the author(s) for a reply and, if considered appropriate by the editorial board, it will be published as discussion in a future issue of the journal.

Proceedings journals rely entirely on contributions from the civil engineering profession (and allied disciplines). Information about how to submit your paper online is available at www.icevirtuallibrary.com/page/authors, where you will also find detailed author guidelines. 